\title{
Assessment of the efficiency of energy- and resource-saving technologies in the model of open innovation
}

\author{
A. I. Shinkevich ${ }^{1, *}$, S. S. Kudryavtseva ${ }^{1}, A$. N. Dyrdonova ${ }^{2}, D$. K. Gallyamova ${ }^{3}$, A. A. Farrakhova ${ }^{1}$, and E. I.Vodolazhskaya ${ }^{1}$ \\ ${ }^{1}$ Kazan National Research Technological University, Kazan, Russia \\ ${ }^{2}$ Nizhnekamsk Chemical Technology Institute (Branch), Kazan National Research Technological University, Nizhnekamsk, Russia \\ ${ }^{3}$ Kazan Federal University, Kazan, Russia
}

\begin{abstract}
The relevance of this work is determined by the fact that the issues of resource-saving technologies implementation in the model of open innovation have not been fully addressed yet and require further study and systematization of the determining factors, which is especially important on the back of the transition to a new technological pattern and the use of the emerging technological opportunity windows. The solution of the problems mentioned will reveal new opportunities for qualitative and quantitative growth of production systems by improving the innovation targeting in the field of resource saving and energy efficiency. The purpose of the article is to identify the functional dependence between the Networked Readiness Index and the emerging technological opportunity windows in order to improve the efficiency of resource-saving technologies in open innovation and production systems. The main research methods underlying the article include the method of description used to identify trends in the Networked Readiness Index across the globe, the correlation analysis method used to identify a close relationship between the Networked Readiness Index and indicators of state support granted to the innovations in production, and the regression analysis method used to build a regression model of the dependence between the resource-saving system and production indicators. The article touches upon the aspects of improving the resource-saving system efficiency in the framework of the open innovation model in the field of production. The correlation between the Networked Readiness Index and the indicators of the state institutions quality characterizing the level of innovation support provided to the industry across the world countries has been revealed, and the functional connection between the use of waste at petrochemical plants and the petrochemical products shipped has been proved using the emerging economies as an example. The materials of the article can be used in the development of strategies and programs aimed to improve the resource-saving system efficiency in petrochemical companies of developing countries, taking into account the emerging technological opportunity windows and technology readiness of the production for innovative transformations.
\end{abstract}

\section{Introduction}

The global financial and economic crisis predetermined changes in the development pathway of national innovation and production systems.

In the context of modern globalization of economic activity, the emergence and replacement of technological patterns becomes large-scale as new production and technical systems spread from the leading countries to the periphery of the world market economy. The integration of new countries into the circle of technically developed economies takes place in the phases of the technological pattern growth. This happens when countries manage to create competitive production on the national economic scale in the course of the replacement of technological patterns and structural realignment of the world economy. At the same time, to regard a country as a developed economy, certain social and economic, scientific and technical prerequisites are required such as a developed industrial potential, certain level of education of the population, the existence of national engineering and humanitarian elite, as well as access to external sources of information, capital and resources. All these prerequisites are formed over the life cycle of the technological pattern preceding the great leap.

The opportunities of the expansion of the fifth innovation wave in most of the world economies will soon fade away, and the global economic system will be transformed into a new technological pattern with such cornerstone industries as resource-saving technologies, intelligent transport systems, bio-and cognitive technologies, artificial intelligence, global information networks, etc.

As the new stage of technological development is being formed, we can observe the development of a cross-functional vector, a new technological culture converging nano-bio-info-cognitive (NBIC) technologies

\footnotetext{
*Corresponding author: ashinkevich@mail.ru
} 
- based on the study of the mind and behavior of living beings, especially humans. In recent studies, NBIC technologies are supplemented by social technologies, forming NBICS. These are theoretical and methodological, scientific and practical bases of technoscience development management underlain by the principles of self-development. At the heart of technoscience is the transition from cognitive to engineering activities. Science is considered as a new form of interaction with technologies. NBICS convergence will allow creating new scientific research methodologies, engineering paradigms and industrial products that will enhance the mental (intellectual) abilities of a human being as well as socialization. An integrated approach to addressing integral problems from different spheres of life requires the integration of relevant differentiated very specific professional expertise. NBICS technologies focus on the convergent development of different areas of scientific knowledge, suggesting that changes occurring in one area of knowledge can be used as tools, methods and approaches to solving problems emerging in other areas of knowledge. Thus, NBICS convergence can be considered as an open innovation model, allowing the integration and systematic movement of interdisciplinary knowledge and providing their synergetic effect and interpenetration.

In this regard, in the context of the world economic system transformation, the criterion for the efficiency of the innovative production systems development becomes the timely re-orientation of resources from technologically backward industries to key sectors that form the core of the new technological pattern. Depending on how quickly and fully technological diversity can be eliminated and breakthrough growth of key sectors can be achieved with appropriate financial, organizational and institutional support provided by the state to the innovative economic sector, the national economic system as a whole can become efficient and competitive.

In this regard, the most important task faced by the world countries becomes the modernization of the economic structure. The promotion and continuity of innovation begin to play a crucial role in the technological development. The focus is shifting towards the introduction of product and process innovations in the companies' resource-saving and energy efficiency systems.

\section{Literature review}

The problems of administrative and technological innovations implementation are reflected in numerous works of researchers, for example, the effect of random change on innovation activities [1], the use of innovation to overcome the crisis of organizations [2], radical innovation [3], innovation in the knowledge economy [4], social responsibility of innovation-related activities [5], innovative behaviour of project team leaders in companies [6], the influence of strategic partnerships on the innovation outcomes [7], modelling innovation activities in different types of economic systems [8], open national innovation systems [9]. Despite sufficient coverage of the aspects associated with the innovations in the industrial complex and their social responsibility, in our opinion, not enough attention has been paid to the specifics of the use of open innovations within the framework of the resource and energy-saving technologies systems that would allow us to consider the technological process of production not as a separate element of production, but as a certain link in the supply chain of final products.

The problems of greening the industry and improving the resource-saving systems efficiency through innovation are reflected in the following studies: environmental certification and technical efficiency [10], planning of highly hazardous component inventory [11], innovative developments in oil and gas production [12], flexible solutions in production systems [13], and digitalization of open innovation systems as a factor of their efficiency improvement [14]. According to the works mentioned, today, on the back of technological modernization, industrial production is focused on innovative technological systems that can provide high economic efficiency, resource saving and quality improvement. At the same time, it becomes obvious that in order to address the task of improving the production system organization efficiency, we have to identify and develop necessary control mechanisms that are of particular importance for the industrial sectors with a high proportion of energy-intensive industrial products, such as the petrochemical complex. In our opinion, the development of resource management models should be based on the identification of the internal potential of innovation and production systems, depending on the specifics of the industry, in which they operate, as well as the institutional and technological environment, which is not fully represented in the research dedicated to this topic.

In addition, notwithstanding the availability of an extensive theoretical and methodological array of data and practical solutions, there is still no single methodology for the open innovation and production complexes management in economic systems, which would combine the latest achievements of modern management science and take into account the peculiarities of the prerequisites needed for the emergence of a new technological pattern in the global economic system. In most cases, the studies mentioned are controversial and fail to duly account for the technology readiness and emerging technological opportunities for the improvement of the resource-saving system efficiency and the competitiveness of the industry.

\section{Results and discussions}

Transition to the sixth wave of innovation is connected, first of all, with qualitative transformation of the management structure. Currently, in the context of the information economy development, Networked Readiness Index becomes an increasingly important as 
an indicator in international practice, reflecting the potential of a certain state. The dependence between the Networked Readiness Index and the economic development level is published by the World Economic Forum and the INSEAD business school, where all countries are ranked by the "Network (Technology) Readiness Index" to energy- and resource-saving technologies [15].

In recent years, this index has become one of the most important indicators of the potential and development opportunities of countries. It seems reasonable to use this index for the assessment of the potential ability of an economy to transit to the sixth wave of innovation.

We should note that the extinction of the fifth technological pattern will take place in 2020s-2030s, when most of the economically developed countries will possess these technologies in full. Their widespread diffusion will lead to the following changes:

- in approaches and ways to achieve environmental safety and protection of the environment;

- in the development of renewable sources of energy, the introduction of green and energy-saving technologies, which will lead to diminished dependence on traditional sources of natural resources;

- in the design of "smart houses", an intellectual system of housing and communal services, which will increase the level of the people's ecosystem comfort.

At the same time, chains of creation of high added value in high-tech economy sectors and a sphere of scientific and research works will tend towards BRICS and other developing countries. The economic effect from the diffusion of the current key fifth technological pattern will reach its peak in 2010-2020s. In addition, at the present moment, main trends of the emerging sixth technological pattern are being formed. The relative boundary between the fifth and the sixth technological patterns consists, first of all, in the design and acquisition of technologies based on the new fundamental approaches; second, in the leading role of information in macro-economic and technological development; third, in the usage of cognitive technologies and artificial intelligence systems in the technological process.

Issues of the transition of a state towards new technological pattern are mainly determined by the chance of rapid development that appears in conditions of the global crisis in technologically lagging countries. In particular, new emerging industries and sectors of the economy and their rapid acquisition transfer economies of the developing countries to a qualitatively new wave of growth. Increasing structural disproportions in world economy require mobilization of resources for the goals of advanced development [16-19].

Prerequisite for systematic innovative growth, using emerging technological windows of possibilities and harmonious social and economic development of the system is the creation and operation of institutional structure. It is known that it is the institutional structure that ensures effective management of the innovative system. Determining the structure and framework of human relations, it decreases the degree of uncertainty, diminishes management risks and thus contributes to the increased system's manageability and effectiveness of decisions taken ensuring conditions of innovative development. The choice of the development strategy should be based upon diagnostics of the state of the economy and institutional structure. Otherwise the transition to the sixth technological pattern will be impossible in the conditions of a completely unaccommodated institutional structure and in the situation of institutional imperfection of the state regulation of the new quality of economic growth, which is expressed primarily in low effectiveness of the state at decision of key issues in in the sphere of innovative modernization of the economy. Comparative

Table 1. Networked Readiness Index to energy- and resource-saving technologies in 2009-2015 in world countries.

\begin{tabular}{|c|c|c|c|c|c|c|}
\hline \multirow[b]{2}{*}{ Country } & \multicolumn{2}{|c|}{2015} & \multicolumn{2}{|c|}{$2010-2011$} & \multicolumn{2}{|c|}{$2009-2010$} \\
\hline & $\begin{array}{c}\text { Networked } \\
\text { Readiness Index }\end{array}$ & Rank & $\begin{array}{c}\text { Networked } \\
\text { Readiness Index }\end{array}$ & Rank & $\begin{array}{l}\text { Networked } \\
\text { Readiness } \\
\text { Index }\end{array}$ & Rank \\
\hline Singapore & 6.0 & 1 & 5.59 & 2 & 5.64 & 2 \\
\hline Finland & 6.0 & 2 & 5.43 & 3 & 5.44 & 6 \\
\hline Sweden & 5.8 & 3 & 5.60 & 1 & 5.65 & 1 \\
\hline Norway & 5.8 & 5 & 5.21 & 9 & 5.22 & 10 \\
\hline Switzerland & 5.7 & 6 & 5.33 & 4 & 5.46 & 5 \\
\hline USA & 5.6 & 7 & 5.33 & 5 & 5.46 & 5 \\
\hline Canada & 5.5 & 11 & 5.21 & 8 & 5.36 & 7 \\
\hline South Korea & 5.5 & 12 & 5.19 & 10 & 5.14 & 10 \\
\hline Denmark & 5.5 & 15 & 5.29 & 7 & 5.54 & 3 \\
\hline Taiwan & 5.5 & 18 & 5.30 & 6 & 5.20 & 11 \\
\hline Russia & 4.5 & 41 & 3.69 & 77 & 3.58 & 80 \\
\hline Turkey & 4.4 & 48 & 3.79 & 71 & 3.68 & 69 \\
\hline Italy & 4.3 & 55 & 3.97 & 51 & 3.97 & 48 \\
\hline Ukraine & 4.0 & 71 & 3.53 & 90 & 3.53 & 82 \\
\hline Tajikistan & 3.2 & 117 & 3.23 & 112 & 3.09 & 109 \\
\hline Chad & 2.4 & 143 & 2.59 & 138 & 2.57 & 133 \\
\hline
\end{tabular}


Table 2. Quality indicators of state institutions in the world.

\begin{tabular}{|c|c|c|c|c|c|c|}
\hline Country & $\begin{array}{c}\text { Visibility } \\
\text { and } \\
\text { accountabilit } \\
y\end{array}$ & $\begin{array}{l}\text { Political } \\
\text { stability }\end{array}$ & $\begin{array}{c}\text { Effectiveness } \\
\text { of the } \\
\text { Government }\end{array}$ & $\begin{array}{l}\text { Quality of } \\
\text { legislation }\end{array}$ & $\begin{array}{l}\text { Degree of } \\
\text { law } \\
\text { supremacy }\end{array}$ & $\begin{array}{l}\text { Level of } \\
\text { corruption }\end{array}$ \\
\hline Sweden & 1.53 & 1.13 & 1.99 & 1.68 & 1.90 & 2.24 \\
\hline Singapore & -0.41 & 1.33 & 2.53 & 1.92 & 1.73 & 2.34 \\
\hline Finland & 1.48 & 1.36 & 1.95 & 1.58 & 1.87 & 2.34 \\
\hline Switzerland & 1.45 & 1.23 & 2.06 & 1.66 & 1.86 & 2.15 \\
\hline USA & 1.12 & 0.59 & 1.65 & 1.58 & 1.65 & 1.55 \\
\hline Taiwan & 0.70 & 0.72 & 0.88 & 1.07 & 0.77 & 0.55 \\
\hline Denmark & 1.48 & 1.00 & 2.19 & 1.86 & 1.92 & 2.32 \\
\hline Canada & 1.43 & 1.03 & 1.93 & 1.66 & 1.81 & 2.03 \\
\hline Norway & 1.53 & 1.33 & 1.95 & 1.34 & 1.96 & 1.88 \\
\hline South Korea & 0.59 & 0.41 & 1.26 & 0.73 & 0.79 & 0.45 \\
\hline Italy & 0.96 & 0.41 & 0.39 & 0.95 & 0.43 & 0.13 \\
\hline Turkey & -0.19 & -0.73 & 0.20 & 0.20 & 0.09 & 0.10 \\
\hline Russia & -0.97 & -0.62 & -0.32 & -0.56 & -0.91 & -0.98 \\
\hline Ukraine & -0.03 & -0.01 & -0.60 & -0.39 & -0.62 & -0.72 \\
\hline Tajikistan & -1.32 & -0.74 & -0.88 & -0.97 & -1.12 & -0.99 \\
\hline Chad & -1.45 & -1.92 & -1.48 & -1.26 & -1.57 & -1.45 \\
\hline
\end{tabular}

characteristic of world state institutions as the institutional support of a transition to the new technological pattern is reflected in Table 2 [20].

The conducted research showed the presence of a close positive relation between the networked readiness index and indicators of quality of the state institutions that characterize the level of support for innovations in production. With "indicator effectiveness of the Government" the correlation coefficient made 0.9306, with indicator "Degree of law supremacy" -0.8985 , and with level of corruption -0.8793 (Table 3 ).

The coefficients obtained are statistically important (p-meaning <0.05). Consequently, the higher the quality of state institutions, the more likely the networked readiness index of the country will be that will stimulate search and development of new technologies, as well as reorientation of resources towards the development of a new technological pattern.

\section{Conclusions}

Thus, the perspective of developing macro technologies of the fifth and sixth technological patterns in innovation and production systems is directly influenced by the quality of state institutions supporting technological innovations in production: visibility and accountability, political stability, effectiveness of the Government, quality of legislation, degree of law supremacy, and level of corruption. In our opinion, achieving breakthrough in innovative development becomes viable at the change of technological patterns through transit of the first and the fourth phases of the life cycle of technological wave, which is characterized by emerging technological opportunity windows. At the same time, we consider the achievement of technological transformation mostly justified subject to usage of open innovations model, which helps to use emerging technological windows in the more effective and dynamic way.

Table 3. Networked Readiness Index to energy- and resource-saving technologies in 2009-2015 in world countries.

\begin{tabular}{|c|c|c|r|r|r|r|r|}
\hline Indicators & $\begin{array}{c}\text { Network } \\
\text { ed } \\
\text { readiness } \\
\text { index }\end{array}$ & $\begin{array}{c}\text { Visibility } \\
\text { and } \\
\text { accountabili } \\
\text { ty }\end{array}$ & $\begin{array}{c}\text { Political } \\
\text { stability }\end{array}$ & $\begin{array}{c}\text { Effectiveness } \\
\text { of the } \\
\text { Government }\end{array}$ & $\begin{array}{c}\text { Quality of } \\
\text { legislation }\end{array}$ & $\begin{array}{c}\text { Degree of } \\
\text { law } \\
\text { supremacy }\end{array}$ & $\begin{array}{c}\text { Level of } \\
\text { corrupti } \\
\text { on }\end{array}$ \\
\hline $\begin{array}{l}\text { Networked } \\
\text { readiness index }\end{array}$ & 1.0000 & 0.6120 & 0.6611 & 0.9306 & 0.8672 & 0.8985 & 0.8793 \\
\hline $\begin{array}{l}\text { Visibility and } \\
\text { accountability }\end{array}$ & 0.6120 & 1.0000 & 0.6167 & 0.7303 & 0.7686 & 0.7289 & 0.7445 \\
\hline Political stability & 0.6611 & 0.6167 & 1.0000 & 0.7413 & 0.7200 & 0.7773 & 0.7553 \\
\hline $\begin{array}{l}\text { Effectiveness of } \\
\text { the Government }\end{array}$ & 0.9306 & 0.7303 & 0.7413 & 1.0000 & 0.9345 & 0.9575 & 0.9506 \\
\hline $\begin{array}{l}\text { Effectiveness of } \\
\text { the Government }\end{array}$ & 0.8672 & 0.7686 & 0.7200 & 0.9345 & 1.0000 & 0.9151 & 0.8895 \\
\hline $\begin{array}{l}\text { Effectiveness of } \\
\text { the Government }\end{array}$ & 0.8985 & 0.7289 & 0.7773 & 0.9575 & 0.9151 & 1.0000 & 0.9632 \\
\hline $\begin{array}{l}\text { Effectiveness of } \\
\text { the Government }\end{array}$ & 0.8793 & 0.7445 & 0.7553 & 0.9506 & 0.8895 & 0.9632 & 1.0000 \\
\hline
\end{tabular}


A system of resource saving can be considered as one of areas of innovative transformations of an economy sector in emerging technological windows, and petrochemical companies can be deemed as a platform of its perfection. However, the study showed that predominance of a partially closed production cycle is still the constraining factor of its development. The article materials could be used for the development of strategies and programs for increasing effectiveness of the resource-saving system in petrochemical companies of the developing countries considering emerging technological windows and networked readiness of a production to innovative transformations.

\section{References}

[1] J. Chen, C. Adamson, Innovation: Integration of random variation and creative synthesis. Academy of Management Review, 40(3), 461-464 (2015)

[2] W. McKinley, S. Latham, M. Braun, Organizational decline and innovation: Turnarounds and downward spirals. Academy of Management Review, 39(1), 88-110 (2014)

[3] L. Alexander, D. Knippenberg, Teams in pursuit of radical innovation: A goal orientation perspective. Academy of Management Review, 39(4), 423-438 (2014)

[4] M. Cano-Kollmann, J. Cantwell, T.J. Hannigan, R. Mudambi, J. Song, Knowledge connectivity: An agenda for innovation research in international business. Journal of International Business Studies, 47(3), 255-262 (2016)

[5] C.A. Un, The liability of localness in innovation. Journal of International Business Studies, 47(1), 44-67 (2016)

[6] J.H. Kang, G.T. Solomon, D.Y. Choi, CEOs' Leadership styles and managers' Innovative behaviour: Investigation of intervening effects in an entrepreneurial context. Journal of Management Studies, 52(4), 531-554 (2015)

[7] Y. Zheng, H. Yang. Does familiarity foster innovation? The impact of alliance partner repeatedness on breakthrough innovations. Journal of Management Studies, 52(2), 213-230 (2015)

[8] A.A. Reznikov, S.S. Kudryavtseva, A.I. Shinkevich, R.M. Sirazetdinov, V.T. Volov, J.V. Torkunova, E.R. Khairullina, I.Y. Litvin, A design of innovative development in the industrial types of economic activity. Mediterranean Journal of Social Sciences, 1(7), 112 (2016)

[9] S.S. Kudryavtseva, A.I. Shinkevich, M.Y. Shvetsov, L.A. Bordonskaya, V.P. Gorlachev, A.E. Persidskaya, \& N.K. Schepkina, National open innovation systems: an evaluation methodology. Journal of Sustainable Development, 6(8), 270-278 (2015)

[10] S.K. Sahu, K. Narayanan, Environmental Certification and Technical Efficiency: A Study of Manufacturing Firms in India. Journal of Industry Competition and Trade, 16(2), 191-207 (2016)

[11] A. Brezavšček, Stochastic approach to planning of spares for complex deteriorating industrial system. Quality Technology and Quantitative Management, 12(4), 465-480 (2016)

[12] C. Carpenter, Innovative developments in Caspian Republics' oil and gas production. Journal of Petroleum Technology, 68(1), 42-45 (2016)

[13] M.E. Narandja, S. Howes, B. Fattahi, The role of soft skills in a challenging environment. Journal of Petroleum Technology, 67(9), 102-108 (2015)

[14] S.S. Kudryavtseva, F.F. Galimulina, I.A. Zaraychenko, N.V. Barsegyan, Modeling The Management System of Open Innovation in the Transition to E-Economy. Modern Journal of Language Teaching Methods, 8(10), 163-171 (2018)

[15] Networked Readiness Index, from: http://reports.weforum.org/global-informationtechnology-report-2015

[16] T.I. Klimenko, A.I. Shinkevich, S.S. Kudryavtseva, M.V. Shinkevich, N.V. Barsegyan, A.A. Farrakhova, I.I. Ishmuradova, Modeling Factors of Environmental Tourism Development in Innovation Economy. Ekoloji, 27, 263-269 (2018)

[17] A.I. Shinkevich, S.S. Kudryavtseva, M.V. Rajskaya, I.V. Zimina, A.N. Dyrdonova, Ch.A. Misbakhova, Integral technique for analyzing of national innovation systems development. Espacios, 39(22), 6 (2018)

[18] Shinkevich, A.I., Kudryavtseva, S.S., Simaeva, E.P., Stolyarova, A.N., Kharisova, G.M. \& Petrova, E.V. (2018b). Transport and communication space development in open innovation model. Espacios, 9(39), 27-36.

[19] A.I. Shinkevich, S.S. Kudryavtseva, E. N. Razdrokov, I.V. Lushchik, E.L. Vodolazhskaya, S.Sh. Ostanina, M. M. Sharafutdinova, Method for Assessing of the Level of National Innovation Systems Openness from the Institutional Approach Perspective. International Journal of Environmental and Science Education, 9, 10505-10515 (2016)

[20] World Bank

http://data.worldbank.org/indicator. 